\title{
KÁRPÁT-MEDENCEI NYERSANYAGOKBÓL KÉSZÜLT KŐESZKÖZÖK FELÜLETI ELVÁLTOZÁSAINAK KVALITATÍV ÉS KVANTITATÍV ELEMZÉSE
}

\author{
Antony Borel, ${ }^{1,2}$ Raphä̈l Deltombe, ${ }^{3}$ Julie Marteau, ${ }^{4}$ Philippe Moreau, ${ }^{3,5}$ Maxence Bigerelle, 3,5 \\ LengYel György, ${ }^{6}$ Mester Zsolt ${ }^{2,1}$ \\ Magyar Régészet 10. évf. (2021), 3. szám, pp. 1-12. https://doi.org/10.36245/mr.2021.3.4
}

Az öskori régészeti köeszközökön végzett nyomelemzés célja, hogy jellemezzük a felületi elváltozásaikat, s ezen keresztül meghatározzuk az eszközök funkcióit és leirjuk az egykori emberek technikával kapcsolatos viselkedését. A módszer megbizhatósága és megismételhetösége körül vannak viták, s a nyomelemzök számára a legföbb nehézséget az jelenti, hogy számszerüsithetö és megismételhetö elemzéseket és értelmezéseket javasoljanak a tafonómiai (természetes eredetü) és az antropogén (az ember általi készitéssel és használattal összefüggö) nyomokra.

A nyomok olyan kísérleti referencia-gyüjteményének a létrehozását céloztuk meg, amely elsösorban azokra a közettípusokra összpontosit, amelyek rendszeresen elökerülnek a magyarországi régészeti lelöhelyeken. Ez a gyüjtemény lehetôvé teszi majd, hogy jellemezzük a készités, a használat és a tafonómiai folyamatok domborzati bélyegeit. Ezek (optikai mikroszkópos megfigyeléssel történö) kvalitatív és (konfokális mikroszkópos felületmérésekkel történö) kvantitatív elemzésén keresztül vizsgáljuk majd, hogy 1) milyen mértékü a felületi elváltozások változékonysága, 2) milyen vizsgálati protokoll teszi lehetövé a felületi domborzati bélyegek azonositását és jellemzését, 3) mik a megfelelö méréstani beállitások, amelyek lehetövé teszik az elváltozási folyamatok megkülönböztetését egymástól.

Ebben a cikkben bemutatjuk annak az elökészitö kisérletnek az eredményeit, amelyben hat különbözö nyersanyagból készült szilánkokkal munkáltunk meg csontot és nádat. Beigazolódott, hogy mindegyik szilánkon azonosithatók a használati nyomok. A nyomok referencia-gyüjteményének elsö képei mellett röviden bemutatjuk a projekt következö lépéseit is.

Kulcsszavak: őskor, használati nyom, kőtechnológia, felületelemzés, domborzati bélyeg, Kárpát-medence

\section{BEVEZETÉS}

Hogyan készültek az eszközök az őskorban? A különböző embercsoportok vagy éppen a különböző emberfajok eltérő technikákat alkalmaztak-e eszközeik készítéséhez? Használható volt-e minden kőszilánk, s vajon használták is őket? A szerszámokat közvetlenül kézbe fogták vagy pedig nyélbe foglalták? Vajon bőr, csont, növények vágására, kaparására, átlyukasztására stb. szolgáltak-e? Ezek az őskori eszközökre vonatkozó kérdések alapvetőek ahhoz, hogy megérthessük az egykori emberek mindennapi életét, hogy leírhassuk a környezethez való viszonyukat, és hogy azonosíthassuk a technikai alkalmazkodásukat.

Ezek a kérdések évtizedeken át komoly fejtörést okoztak a régészeknek, akik aztán kifejlesztettek egy tudományterületet, amely azoknak a módszereknek és technikáknak a kutatásával foglalkozik, amelyekkel az egykori emberek létrehozták és átalakították szerszámaikat: ez a tipo-technológiai megközelítés (pl. BORDES 1961; TIXIER 1963). Az őskőkori eszközkészítési technikák megértését célzó kísérleti vizsgálatokra is elég korán sor került (COUTIER 1929). Mégis csak az 1940-es években kezdődött rendszeres kutatás

\footnotetext{
1 Histoire Naturelle de l'Homme Préhistorique (HNHP), Muséum national d'Histoire naturelle, CNRS, UPVD, 1 Rue René Panhard, 75013 Paris, Franciaország.

Eötvös Loránd Tudományegyetem BTK Régészettudományi Intézet, 1088 Budapest, Múzeum krt. 4/B.

Université Polytechnique Hauts-de-France, LAMIH, CNRS, UMR 8201, 59313 Valenciennes, Franciaország.

4 Laboratoire Roberval, Sorbonne Université, Université de Technologie de Compiègne, Centre de Recherches de Royallieu, 60203 Compiègne, Franciaország.

INSA Hauts-de-France, 59313 Valenciennes, Franciaország.

6 Miskolci Egyetem BTK Östörténeti és Régészeti Tanszék, 3515 Miskolc-Egyetemváros.
} 
Antony Borel et al. • Kárpát-medencei nyersanyagokból készült köeszközök felületi elváltozásainak elemzése
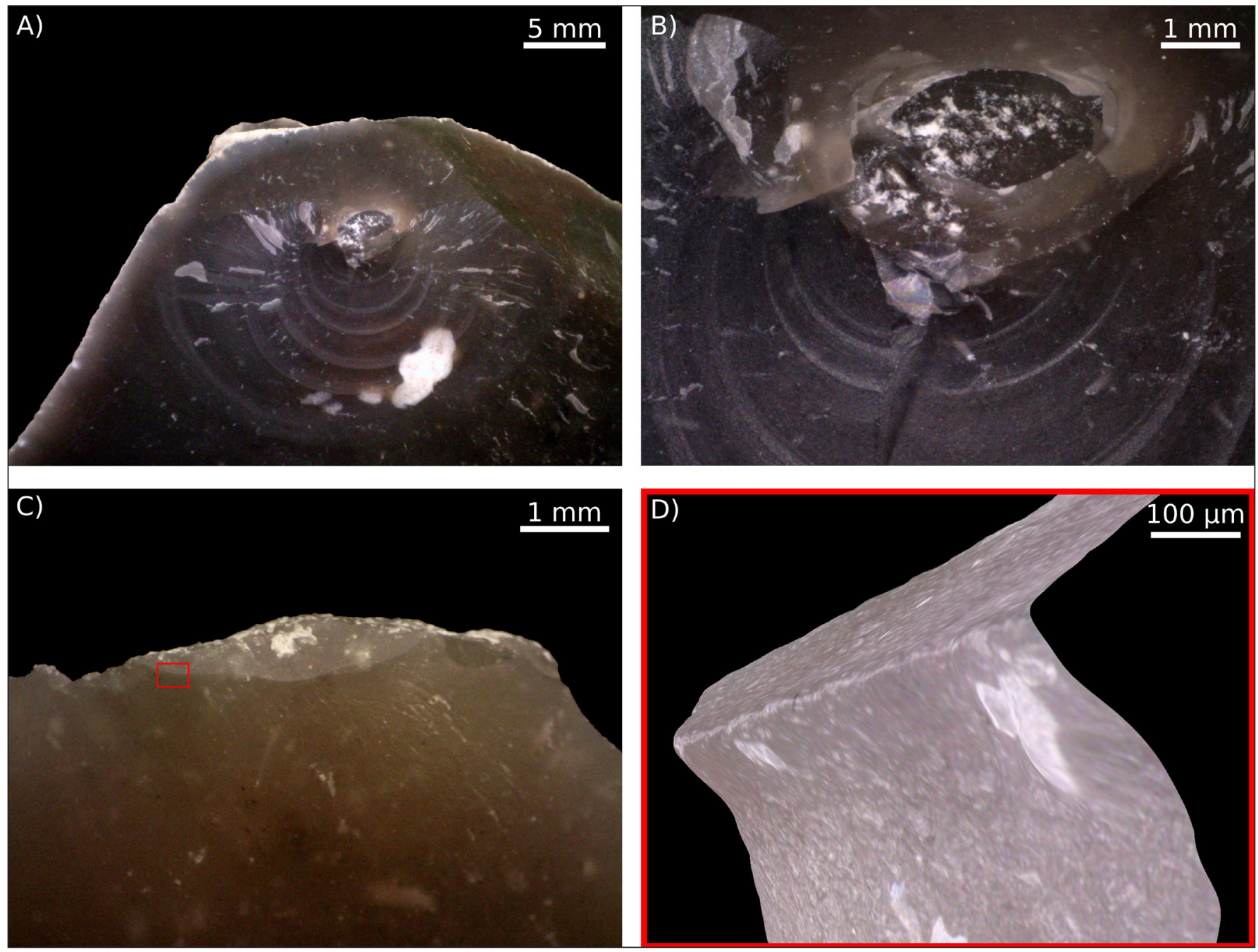

1. kép. Közvetlen ütés nyomai szilánkokon köütő (A, B) és agancsütő (C, D) használata esetén. A C jelü fotón levő szilánk talonján látszanak az agancs anyagmaradványai. Ugyanott a piros négyszög jelzi a D jelü fotón bemutatott $3 D$ modell helyét. A D jelü fotón a lépték azt a becsült értéket mutatja, amely (a Helicon Focus szoftverrel készült) modellhez felhasznált 2D képek léptékei alapján lett kiszámítva

azzal a céllal, hogy találjanak olyan kritériumokat, amelyek lehetővé teszik a régészeti kőeszközleletek készítési technikáinak azonosítását (BORDEs 1947). Az 1960-as évektől kezdve több kutató végzett tudományos kísérleteket, amelyek hozzájárultak a különböző feldolgozási módok (debitázsok) rekonstruálásához. Mindazonáltal kevés figyelmet fordítottak arra, hogy rögzítsék a különböző pattintási technikák jellegzetes lenyomatait (lásd INIZAN et al. 1999). Személyes tapasztalatokra alapozva felvázoltak összefüggéseket egyes felületi jelenségek és egyes pattintási technikák között, ám más megfigyelések ezeket megkérdőjelezték (TIXIER 1982). Szilánkok (és pengék) előállítására irányuló kontrollált kísérletek során kimutatták, hogy vannak összefüggések az előállított termékek metrikus-morfológiai paraméterei és a pattintási művelet fizikai paraméterei, valamint a nyersanyag tulajdonságai között (DibBle \& Pelcin 1995; DibBle 1997; ANDREFSKY 2008; EREN et al. 2014; LengYel \& CHU 2016). Ugyanakkor nagyon ritkák az olyan tanulmányok, amelyek a különböző pattintási technikák által hagyott nyomokkal (1. kép) foglalkoznak (PeLEGRIN, 2000; Driscoll \& García-Rojas, 2014), azok pedig szinte teljesen hiányoznak, amelyek a nyomok számszerüsítésével vizsgálnák a változékonyságukat.

A tárgyaknak (esetünkben a kőeszközöknek) a felülete van leginkább kitéve a külső kontaktusoknak, s ezáltal közvetlenül érinti a környezetből érkező mindenféle fizikai és kémiai behatás. Legyenek bár tafonómiai vagy antropogén eredetủek ezek a behatások, a legtöbbjük megváltoztatja a felület domborzatát (BROwn et al. 2018). Így a kőeszközökön látható felületi domborzati bélyegek megfigyelése és jel- 
Antony Borel et al. • Kárpát-medencei nyersanyagokból készült köeszközök felületi elváltozásainak elemzése

lemzése megbízható támpontot szolgáltat azokra a folyamatokra nézve, amelyeken az eszközök átmentek. Ezen az alapelven született meg és fejlödött ki a traszológia (más néven funkcionális megközelítés vagy nyomelemzés). Ez a tudományterület a szerszámok használatának meghatározására és jellemzésére összpontosít (pl. Semenov 1964; KeELEY 1980), célul tüzve ki a funkciójuk beazonosítását a karcolódások, mikrocsorbulások, legömbölyödések, mikrokopások és anyagmaradványok alapján (pl. Borel et al. 2014; STEMP et al. 2015; lásd még Burroni et al. 2002; 2. kép). Ennek a tudományterületnek a régészeti leletanyagokra való alkalmazása akkor kezdett nemzetközivé válni, amikor lefordították oroszról angolra SEMENOV alapvető művét (1964), amelyet úttörő kutatásairól írt. Azóta a nyomelemzés hatalmas fejlődésen ment keresztül, ám számos ellentmondás és vita is felmerült a módszer megbízhatóságára és megismételhetőségére vonatkozóan, s ezek még ma is érvényben vannak (Odell \& Odell-Vereecken 1980; NewCOMER et al. 1986; Moss 1987; Bamforth 1988; Hurcombe 1988; Rots et al. 2006; CHAN et al. 2020). Mára elfogadottá vált ugyan, hogy a nyomelemzés értékes támpontokat ad ahhoz, hogy jobban megértsük, hogyan és milyen kontextusban használták a múltbeli eszközöket, a (főként kvalitatív) elemzések és értelmezések nagymértékben függenek attól, hogy a megfigyelést végző szakember milyen tapasztalattal rendelkezik, hogyan ítéli meg a látottakat, valamint az ezekből fakadó részrehajlástól. Így hát a legtöbb
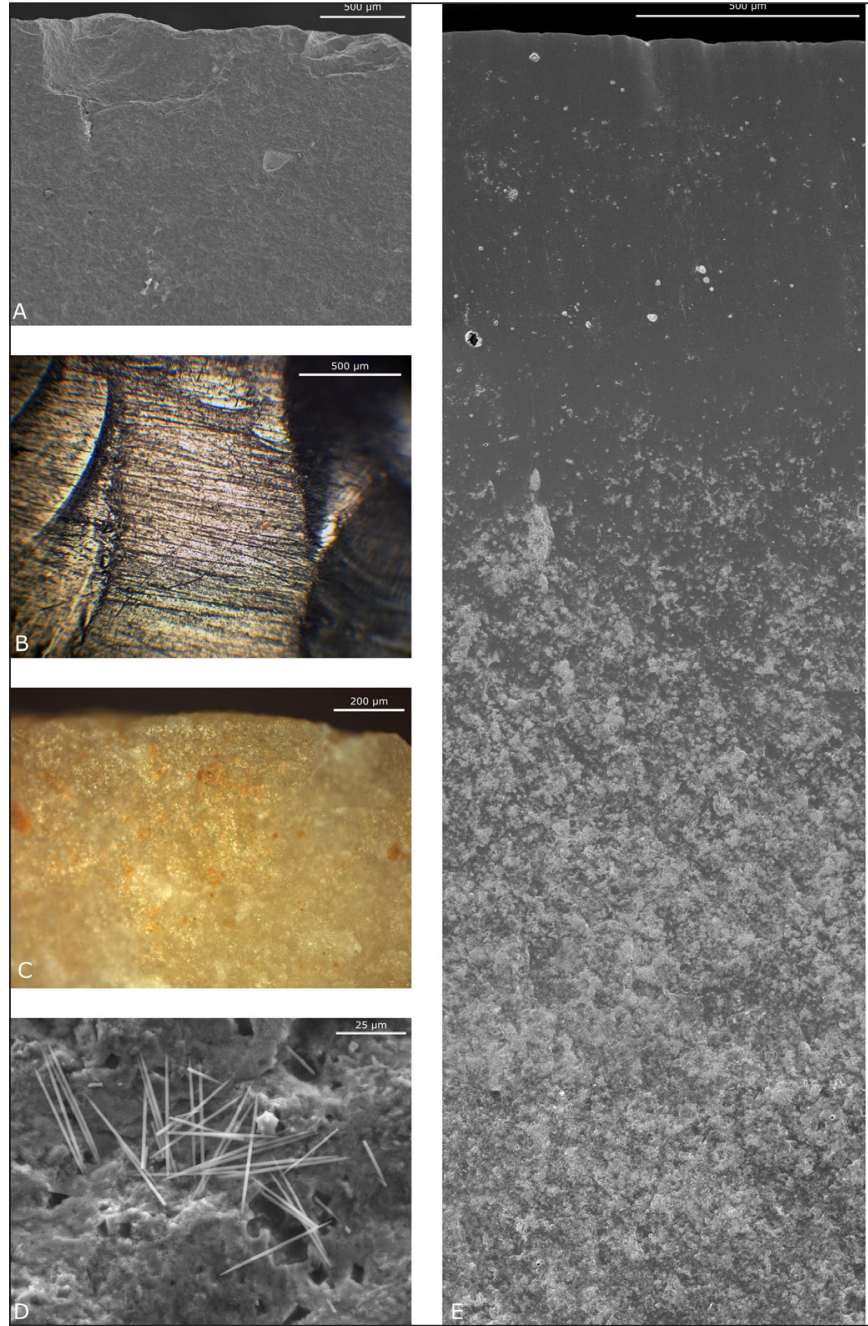

2. kép. Nyomok típusai, amelyek alapján a régészeti köeszközök funkcióját meg lehet határozni. A) mikrotörések vagy csorbulások; B) karcolódások; C) legömbölyödés;

D) anyagmaradványok; E) mikrokopás vita abból a tényböl fakad, hogy a nyomok azonosítása föként a régészeti és a kísérleti kőeszközök közötti vizuális analógiákon alapszik, és abból, hogy a mikronyomelemzők számára az egyik legfőbb feladat mai napig az, hogy számszerüsített elemzéseket és igazolható értelmezéseket nyújtsanak. Ezért lényegbevágó a tudományterület jövője szempontjából a kvantitatív módszerek kifejlesztése és/vagy alkalmazása, amelyek kiegészíthetik a továbbra is alapvetőnek számító kvalitatív megközelítést. Az első próbálkozások kvantitatív módszerek alkalmazására a nyomok azonosításában valójában nem új keletüek (pl. Semenov 1970; Semenov \& ShChelinsky 1971; Dumont 1982; TomenchuK 1983; 1988; Grace et al. 1985; Beyries 1988). Mindazonáltal csak az utóbbi két évtized folyamán a felület-felvételezési technológiák (különösen az érintkezésmentes technológiák) jobb elterjedésének köszönhetően lendültek fel a nyomok (mikrokopások) számszerüsítésére irányuló törekvések és az ilyen módszertani fejlesztések. A változtatható fókuszú mikroszkópokkal és a különösen a (lézeres) konfokális mikroszkópokkal végzett vizsgálatok nagyon ígéretes eredményeket adtak, minthogy ez a két technológia képes volt kimutatni a felület egyenetlenségében meglévő eltéréseket a különböző kontaktanyagtól származó mikrokopások között (Evans \& Donahue 2008; Evans \& MaCDONALD 2011; IbáÑEZ et al. 2014; 2016; 2019; Macdonald 2014; Stemp et al. 2018; Álvarez-Fernández et al. 2020; Pichon et al. 2021). Újabban pedig egyre több tanulmány vizsgálta kontrollált vagy éppen robotikus kísérletekben a különböző változók hatását a nyomok kialakulására (KEY et al. 2015; 2018; PfLEGING et al. 2015; 2019; Qiu 2016; Pfleging 2019; CALANDra et al. 2020; Rodriguez et al. 2021), és próbáltak javítani az elemzések 
Antony Borel et al. • Kárpát-medencei nyersanyagokból készült köeszközök felületi elváltozásainak elemzése

megismételhetőségén a felvételezési rendszerek paramétereinek tesztelésével (pl. CALANDRA et al. 2019b) vagy megfigyelési eljárások javasolásával (pl. CALANDRA et al. 2019a).

Mind a tipo-technológiai, mind a funkcionális megközelítés jól kidolgozott ahhoz, hogy alapvető megközelítés legyen, egyrészt a készítési technikák, másrészt a használati folyamatok meghatározásához, amelyeken a kőeszközök keresztül mentek. Azonban, amint azt fentebb bemutattuk, mindkét megközelítés korlátokkal szembesül a pontosság és megismételhetőség terén. Ugyancsak híján vannak kiterjedt kísérleti referencia-gyüjteményeknek, amelyeknek a jól azonosított és számszerüsített paraméterei lehetővé tennék a régészeti kőeszközök készítési technikáira és használatára vonatkozó jellemzési és osztályozási modellek felállítását. Ez különösen igaz azoknak a nyersanyagoknak az esetében, amelyeket a magyarországi régészeti lelöhelyeken talált kőeszközök készítéséhez használtak fel.

\section{A PROJEKT CÉLKITŰZÉSEI}

A jelenlegi projekt célja 1) egy nagy kísérleti referencia-gyüjtemény létrehozása olyan kőeszközökből, amelyek különböző technikákkal készültek, különböző tevékenységekre használták őket és különböző tafonómiai hatásoknak (azaz eltemetődés utáni véletlenszerü vagy természetes folyamatoknak) voltak kitéve, valamint 2) leírni, megmérni és számszerüsíteni az ezek által a felületükön hagyott minden egyes domborzati bélyeget. Ezek után képesek leszünk 3) megbízható és megismételhető nyomosztályozási modelleket alkotni a felületátalakító folyamatoknak a felismeréséhez a magyarországi régészeti lelőhelyeken meglévő kőnyersanyagokra vonatkozóan.

Ezen adatok elemzésével vizsgálhatóvá válik, 1) milyen mértékủ a felületi elváltozások változékonysága az egyes tesztelt tafonómiai és antropogén folyamatokon belül és közöttük, 2) mely megismételhető, reprodukálható és sztenderdizálható protokoll teszi lehetővé a készítési technikák, használati és tafonómiai folyamatok felületi domborzati bélyegeinek azonosítását és jellemzését és 3) mely méréstani geometrikus sajátosságok, léptékek, felbontások és statisztikák alkalmasak arra, hogy megkülönböztessük egymástól az egyes készítési technikákat, használati és tafonómiai folyamatokat.

A projekt még az első fázisánál tart, így itt most a folyamatban lévő kísérletnek azokat az előzetes eredményeit mutatjuk be, amelyek célja felmérni, hogyan reagálnak a használatra a kiválasztott nyersanyagok, s vajon megfelelőek-e a kvalitatív és kvantitatív nyomelemzésre.

\section{FELHASZNÁLT ANYAGOK ÉS MÓDSZEREK}

A felületi domborzati bélyegek kétség kívül függenek a kőzetfajtától, amelyből a szerszám készült. Az őskor folyamán az emberek sokféle kőzetet használtak fel, ám ez a projekt nyolc kőnyersanyagra összpontosít Magyarországról és a környező területekről (3. kép), melyek rendszerint megtalálhatók KözépEurópa régészeti lelőhelyein (MESTER et al. 2012):

- radiolarit a Bakonyból és a Mecsekből, valamint a Nyugati-Kárpátokból Szlovákiából;

- limnoszilicit a Tokaji-hegységből, a Mátrából és a Bükkből;

- kvarcporfír (metariolit) Bükkszentlászló környékéről;

- krakkói jura tüzkő Dél-Lengyelországból.

Az itt bemutatott próbakísérletben ezek a nyersanyagok szerepeltek a mátrai limnoszilicit, a bakonyi és a kárpáti radiolaritok kivételével. Egyetlen kísérletező személy (A. B.) végezte az összes tevé-

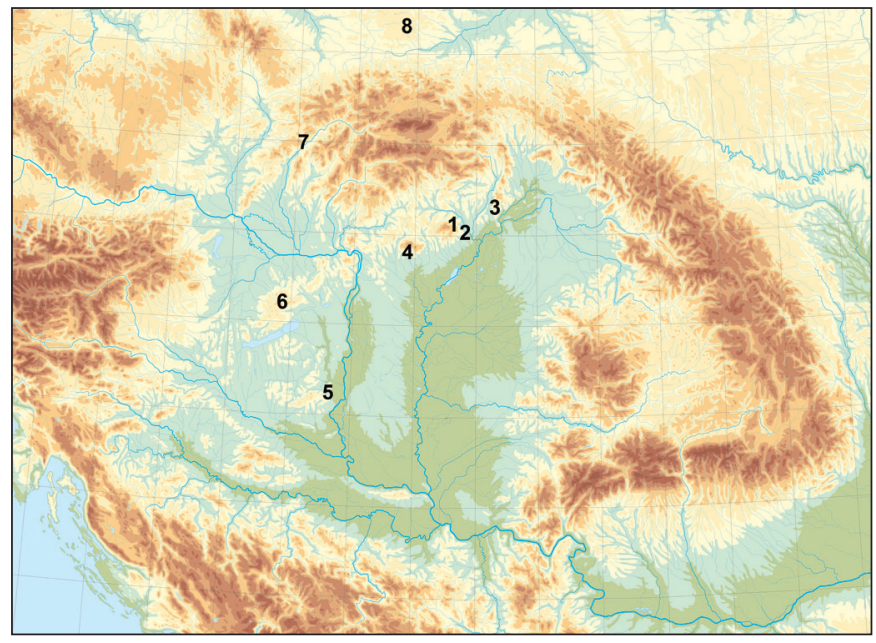

3. kép. A kísérletekhez kiválasztott nyersanyagok származása: kvarcporfir (metariolit) (1) és limnoszilicit (2) a Bükk hegységböl; limnoszilicitek a Tokaji- (3) és a Mátra

(4) hegységböl; radiolarit a Mecsek (5) és a Bakony 6) hegységböl illetve a Nyugati-Kárpátokból (7); krakkói jura tüzkö (8) 
Antony Borel et al. • Kárpát-medencei nyersanyagokból készült köeszközök felületi elváltozásainak elemzése

kenységet, amely magába foglalta 11 szilánk használatát száraz csont kaparására vagy bemetszésére egyenként 2000, 4000 vagy 16000 húzással, illetve frissen vágott nád fürészelését 3200 húzással (1. táblázat). Vizsgálat előtt a szilánkokat ultrahangos fürdőben 15 percen át tisztítottuk semleges kémhatású, foszfátmentes mosószert (5\% Derquim ${ }^{\circledR}$ LM 02) tartalmazó vízben, majd folyóvízzel leöblítettük. A nyomok mikroszkópos dokumentálása Zeiss AxioScope.A1 optikai reflexiós mikroszkóppal történt, amely EC epiplanneofluar 5× (numerikus appertúra [NA]: 0,13, munkatávolság [WD]: 15,8 mm), 10× (NA: 0,25, WD: 9,3 $\mathrm{mm}), 20 \times(\mathrm{NA}: 0,5, \mathrm{WD}: 2,1 \mathrm{~mm})$ és 50× (NA: 0,8, WD: 0,58 mm) objektívekkel rendelkezett. Szükség esetén kiterjesztett mélységélességü képalkotást (stacking) készítettünk Helicon Focus 7.6.4 Pro alkalmazással, illetve panoráma képalkotást (stitching) Microsoft Image Composite Editor 2.0.3.0 alkalmazással.

1. táblázat. A bemutatott projekt elsö lépése keretében elvégzett kisérletek

\begin{tabular}{|c|c|c|c|c|c|c|}
\hline $\begin{array}{l}\text { kísérleti eszköz } \\
\text { azonosítója }\end{array}$ & nyersanyag & származása & $\begin{array}{l}\text { megmunkált } \\
\text { anyag }\end{array}$ & múvelet & időtartam & $\begin{array}{l}\text { húzások } \\
\text { száma* }\end{array}$ \\
\hline Wear2.0HU_01 & limnoszilicit & Bükk hegység, HU & száraz csont & kaparás & $2 \mathrm{~h} 33 \min 20 \mathrm{~s}$ & 16000 \\
\hline Wear2.0HU_02 & jura tüzkő & Krakkó, PL & friss nád & fürészelés & $31 \min 17 \mathrm{~s}$ & 3200 \\
\hline Wear2.0HU_03 & limnoszilicit & Tokaji-hegység, HU & friss nád & fürészelés & $34 \mathrm{~min} 50 \mathrm{~s}$ & 3200 \\
\hline Wear2.0HU_04 & limnoszilicit & Tokaji-hegység, HU & friss nád & fürészelés & $31 \mathrm{~min}$ & 3200 \\
\hline Wear2.0HU_05 & limnoszilicit & Tokaji-hegység, HU & száraz csont & kaparás & $29 \min 43 \mathrm{~s}$ & 4000 \\
\hline Wear2.0HU_06 & limnoszilicit & Tokaji-hegység, HU & friss nád & fürészelés & $26 \min 43 \mathrm{~s}$ & 3200 \\
\hline Wear2.0HU_07 & radiolarit & Mecsek hegység, HU & friss nád & fürészelés & $26 \min 37 \mathrm{~s}$ & 3200 \\
\hline Wear2.0HU_08 & radiolarit & Mecsek hegység, HU & száraz csont & bemetszés & $32 \min 51 \mathrm{~s}$ & 4000 \\
\hline Wear2.0HU_09 & kvarcporfír & Bükkszentlászló, HU & száraz csont & bemetszés & $30 \mathrm{~min}$ & 2000 \\
\hline Wear2.0HU_10 & limnoszilicit & Tokaji-hegység, HU & száraz csont & kaparás & $2 \mathrm{~h} 25 \min 57 \mathrm{~s}$ & 16000 \\
\hline Wear2.0HU_11 & kvarcporfír & Bükkszentlászló, HU & friss nád & fürészelés & $35 \min 35 \mathrm{~s}$ & 3200 \\
\hline
\end{tabular}

*Kaparás és fürészelés esetén egy hátra és egy előre irányú mozdulat együttese felel meg egy húzásnak

\section{EREDMÉNYEK}

Az első eredmények beigazolták, hogy a csont és a nád megmunkálása észlelhető nyomokat (nevezetesen mikrokopást) hagy mindegyik tesztelt nyersanyagon (4-10. kép). Ugyanakkor úgy tünik, a nád fürészelésekor keletkező nyom lassabban fejlődik ki a kvarcporfíron. Valójában 3200 húzás után a mikrokopás pontszerüen jól kifejlett, ám kevésbé kiterjedt a felületen a kvarcporfír esetében (4. kép), ha összevetjük például a jura tüzkövön (5. kép) vagy a mecseki radiolariton (6. kép) keletkezett nyomokkal.

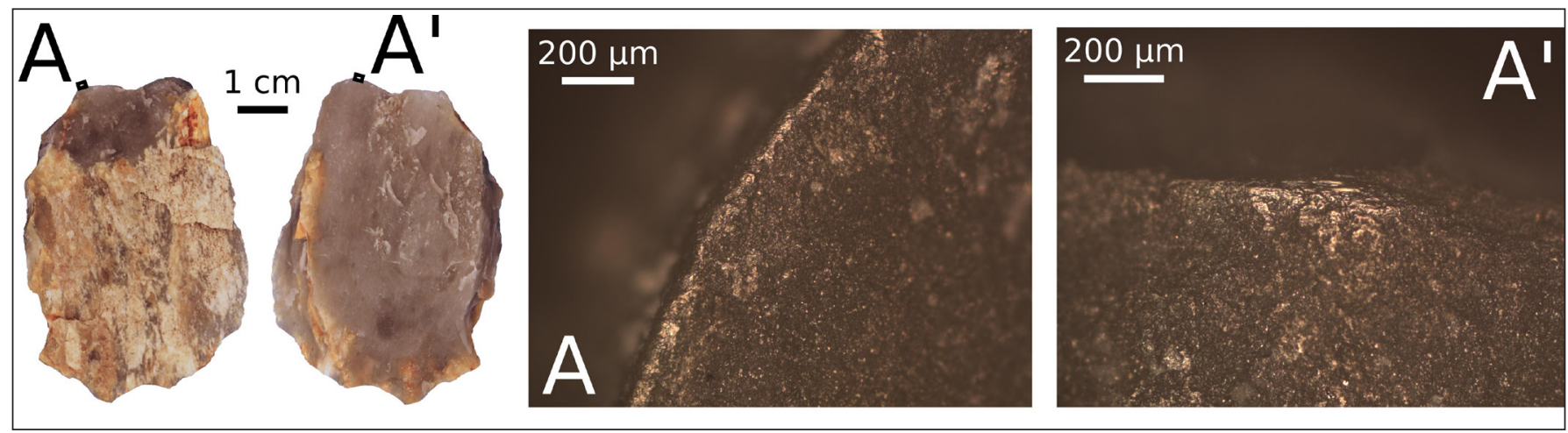

4. kép. Mikrokopás egy kvarcporfírból készitett kísérleti köeszközön (Wear2.0HU_11), amellyel nádat fürészeltek 35 percen át (3200 húzás) 
Antony Borel et al. • Kárpát-medencei nyersanyagokból készült kőeszközök felületi elváltozásainak elemzése
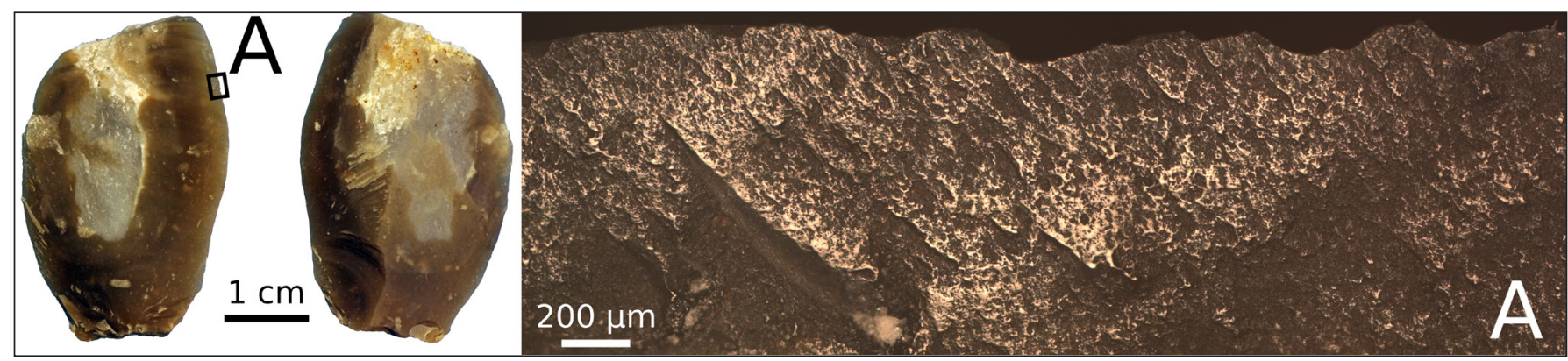

5. kép. Mikrokopás egy krakkói jura tüzköböl készitett kísérleti köeszközön (Wear2.0HU_02), amellyel nádat fürészeltek 31 percen át (3200 húzás)

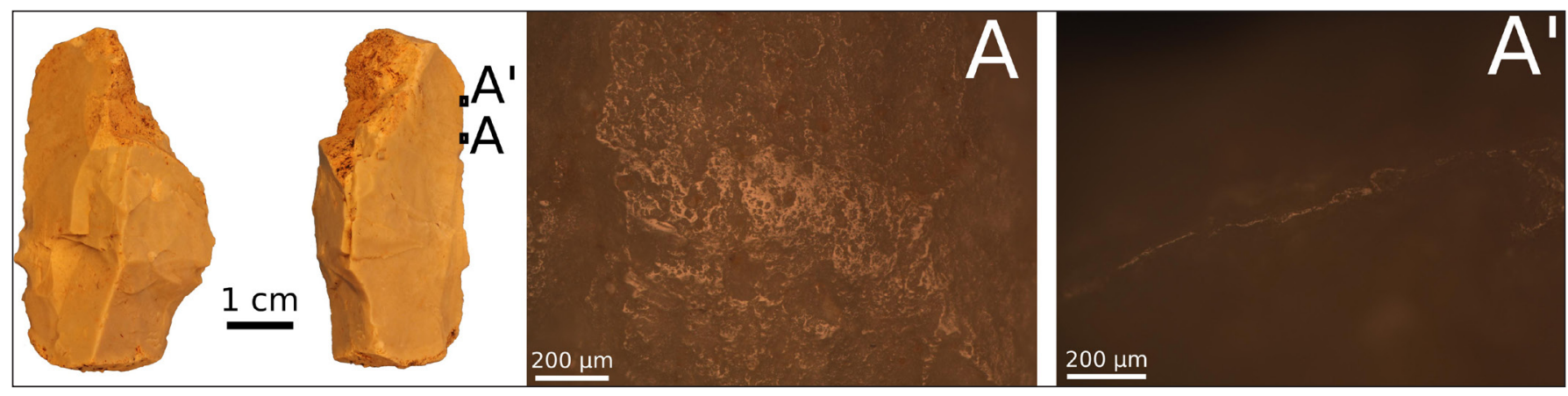

6. kép. Mikrokopás egy mecseki radiolaritból készített kísérleti köeszközön (Wear2.0HU_07), amellyel nádat fürészeltek 26 percen át (3200 húzás)

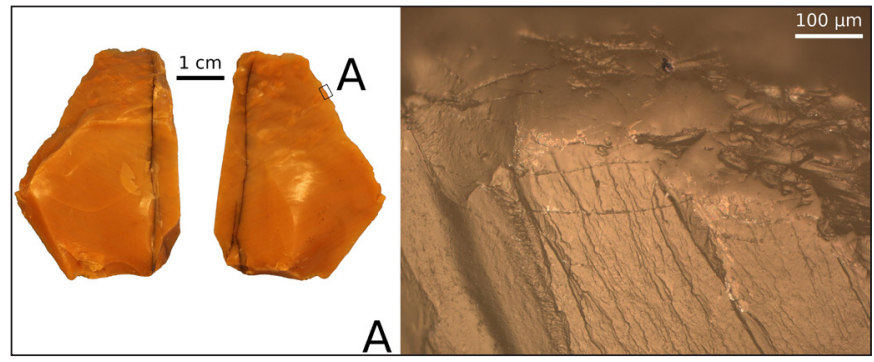

7. kép. Mikrokopás egy Tokaji-hegységi limnoszilicitböl készitett kísérleti köeszközön (Wear2.0HU 05), amellyel csontot kapartak 29 percen át (4000 húzás)

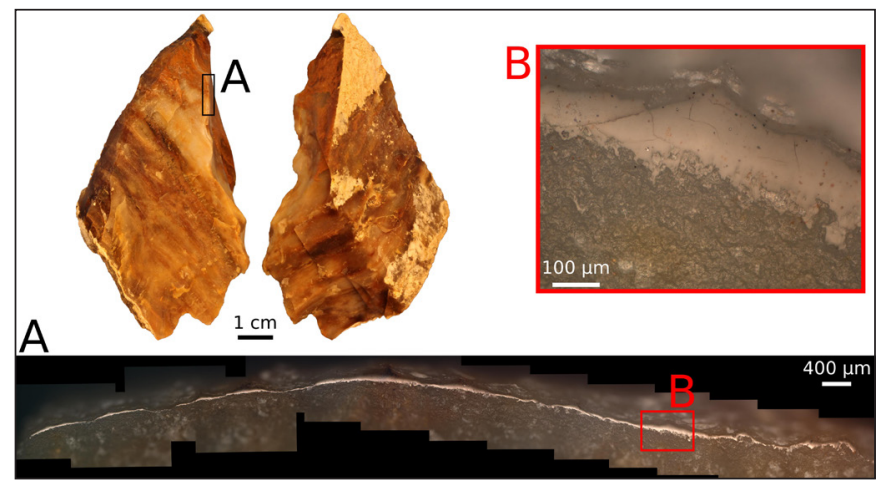

9. kép. Mikrokopás egy bükki limnoszilicitből készitett kísérleti köeszközön (Wear2.0HU 01), amellyel csontot kapartak 2 óra 33 percen át (16 000 húzás)

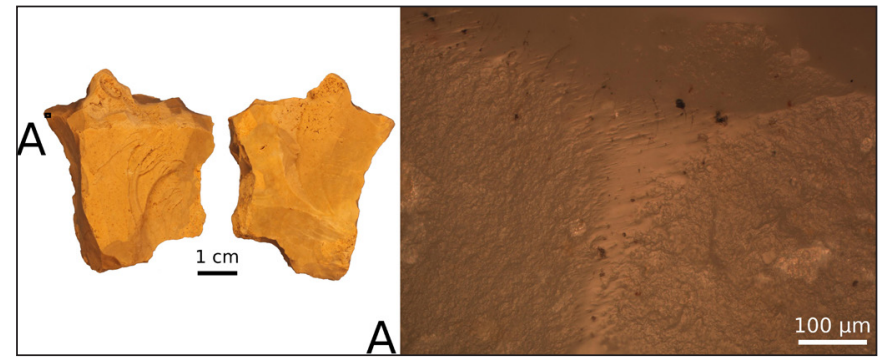

8. kép. Mikrokopás egy mecseki radiolaritból készitett kisérleti köeszközön (Wear2.0HU 08), amellyel csontot kapartak 32 percen át (4000 húzás)
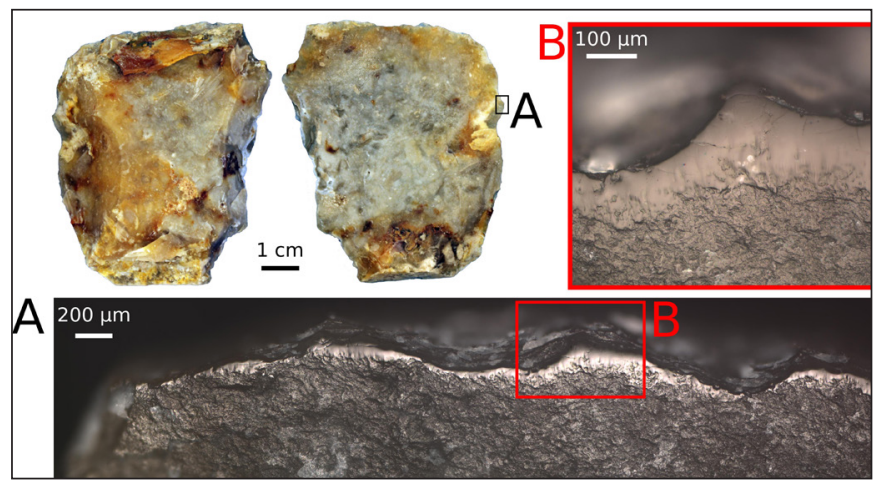

10. kép. Mikrokopás egy rátkai (Tokaji-hegység) limnoszilicitböl készitett kísérleti köeszközön (Wear2.0HU 10), amellyel csontot kapartak 2 óra 25 percen át (16 000 húzás)

A csontmegmunkáláskor a mikrokopás már 4000 húzás után egyenletesen simának mutatkozik mind a Tokaji-hegységből származó limnosziliciten (7. kép), mind a mecseki radiolariton (8. kép). 
Antony Borel et al. • Kárpát-medencei nyersanyagokból készült köeszközök felületi elváltozásainak elemzése

16000 húzás után a mikrokopás tisztán látható a használt élen a bükki limnoszilicit (9. kép) és a Tokajihegységből származó (rátkai) limnoszilicit estében (10. kép). Ez a mikrokopás nagyon egyenletesen sima, és megközelítőleg $100 \mu$ m szélességben terjed ki az él mentén az eszközök felületére.

\section{ELSŐ KÖVETKEZTETÉSEK ÉS PERSPEKTÍVÁK}

Ezzel az első kísérlettel igazolni tudtuk, hogy a használati mikrokopások megfigyelhetők optikai mikroszkóppal mindegyik kiválasztott Kárpát-medencei nyersanyagon. Ismereteink szerint ezeknek a sajátos régióknak a nyersanyagai többnyire még soha nem voltak tesztelve nyomvizsgálat szempontjából.

Ennek az első kísérletnek a folytatásaként széleskörü kísérletek vannak folyamatban. A legtöbb tevékenység esetében nincs korlátozva a részt vevő személyek száma, de az egyének esetleges hatását az eredményekre ki fogjuk értékelni tribométerrel végzett ellenőrzött kísérletek segítségével. Szekvenciális kísérletek (OLLÉ \& VERGÈs 2014) már történtek kétféle mozgás (fürészelés és kaparás) és négyféle kontaktanyag (csont, agancs, fa és nád) alkalmazásával. Első lépésben ezen kontaktanyag-kategóriák közötti különbségeket szándékozunk számszerüsíteni, de a kategóriákon belüli változékonyságot is ki fogjuk értékelni. Nyilvánvaló, hogy például a frissen vágott és a száraz nád vagy a kiszáradt és az átnedvesedett agancs eltérő nyomokat produkál, s így a domborzati bélyegek is eltérnek.

Az itt bemutatott próbakísérlet azt is lehetővé tette, hogy teszteljük a különböző technológiákat, és kiválasszuk a legmegfelelőbbet a kőeszközök felületeinek a méréséhez. Ennek eredményeként lézer konfokális mikroszkópi eljárással fogjuk dokumentálni mindegyik felületet (pl. EvANS \& MACDONALD 2011; STEMP et al. 2018). A használat előtt és után megmért felületek összevetésével tudjuk számszerüsíteni a domborzati bélyegek változékonyságát a mozgások és kontaktanyagok függvényében, valamint a bélyegek alakulását a használati ciklusokon keresztül (vagyis a húzások számának növelésével).

Kísérleti kőeszköz-előállítást is végzünk, amelynek keretében három kísérletet végző személy fog szilánkokat és pengéket létrehozni különböző pattintási technikákkal: közvetlen ütéssel kemény és lágy kőütővel, fa- és agancsütővel. Mindegyik előállított darabot részletesen megvizsgálunk makroszkóposan és kis nagyításban binokuláris mikroszkóppal. Egy részüket kiválasztjuk a megfigyelt pattintási stigmák változékonysága alapján, hogy megvizsgáljuk és megmérjük a felületi domborzati bélyegeiket is.

Annak érdekében, hogy elkerülhető legyen a készítési és használati tevékenységeknek a domborzati bélyegekre alapozott helytelen azonosítása, vizsgáljuk a természeti vagy véletlenszerü folyamatok hatására keletkező nyomokat is. Kétféle tafonómiai kísérletet fogunk végezni: a taposás és az üledék általi súrlódás hatását.

A készítésből, használatból és tafonómiai folyamatoktól származó, fent említett domborzati bélyegek leírása és megmérése, s ezen felül a változékonyságuk kiértékelése elsőként lehetővé teszi majd kontaktanyag-kategóriák megkülönböztetését. A projekt nyílt végü marad, így a folyamatosan hozzáadódó új kísérleti és felülettopográfiai adatok állandóan növelik a létrejövő modellek megbízhatóságát, s így később valószínüleg támpontot fog adni a kontaktanyag-típusok és tevékenységek sokkal pontosabb meghatározásához. Mind az új kísérleti referencia-gyüjtemény, mind a felületi méréseken alapuló statisztikai modellek új összehasonlító adatokat szolgáltatnak majd a Kárpát-medence lelőhelyein előkerült régészeti kőeszközök értelmezéséhez. A kísérleti referencia-gyüjtemény a budapesti Eötvös Loránd Tudományegyetem Régészettudományi Intézetének archeometriai laboratóriumában lesz elhelyezve és kezelve. A kezelésből vagy például a tárolóanyagokkal való kontaktusból származó esetleges felülettopográfiai módosulásokat vagy változásokat a kőeszközökön rendszerességgel elvégzett ellenőrző mérésekkel fogjuk dokumentálni.

\section{KÖSZÖNETNYILVÁNÍTÁS}

A kísérletekben felhasznált nyersanyagok az NKFIA által támogatott „A kőnyersanyag-forrásokkal való gazdálkodás változásai a középső paleolitikumtól a középső neolitikumig Észak-Magyarországon” (K 124334) projekt gyűjteményéből származtak. A bemutatott elemzések az NKFIA által támogatott „Kőeszközök felületi elváltozásainak kvalitatív és kvantitatív elemzése: digitális és fizikai referenciagyüjtemény létrehozása magyarországi kőnyersanyagok készítési és használati nyomainak jellemzésére” (K 132857) 
Antony Borel et al. • Kárpát-medencei nyersanyagokból készült köeszközök felületi elváltozásainak elemzése

projekt keretében valósultak meg. A próbakísérletnél felhasznált mikroszkóp beszerzése az USZT KMOP4.2.1/B-10-2011-0002: „Interdiszciplináris, innovatív kutatási irányok és az ipari kooperáció infrastrukturális hátterének fejlesztése valamint új oktatási technológiák bevezetése az ELTE-n" projekt keretében történt. Köszönettel tartozunk a GDR SurfTopo (CNRS GDR 2077) francia kutatócsoportnak a felületdomborzati vizsgálatokhoz nyújtott inspiráló kutatási környezetért. Hálánkat fejezzük ki Dósa Istvánnénak és azoknak a vadászoknak és henteseknek is, akik a kísérleteinkben felhasznált csontokat, agancsokat és böröket a rendelkezésünkre bocsátották.

IRODALOM

Álvarez-Fernández, A., García-González, R., Márquez, B., Carretero, J. M. \& Arsuaga, J. L. (2020). Butchering or wood? A LSCM analysis to distinguish use-wear on stone tools. Journal of Archaeological Science: Reports 31, 102377. https://doi.org/10.1016/j.jasrep.2020.102377

Andrefsky, W. Jr. (2008). Lithic Technology: Measures of production, use, and curation. New York: Cambridge University Press.

Bamforth, D.B. (1988). Investigating microwear polishes with blind tests: The institute results in context. Journal of Archaeological Science 15, 11-23. https://doi.org/10.1016/0305-4403(88)90015-5

Beyries, S. (1988). Industries Lithiques: tracéologie et technologie. Volume 1: Aspects archéologiques. Centre de Recherches Archéologiques du CNRS. ed. BAR International Series 411. Oxford: Archaeopress.

Bordes, F. (1947). Etude comparative des différentes techniques de débitage et de la typologie du Paléolithique ancien et moyen. L'Anthropologie 51, 1-29.

Bordes, F. (1961). Typologie du Paléolithique ancien et moyen. Institut de Préhistoire de l'Université de Bordeaux.

Borel, A., Ollé, A., Vergès, J. M. \& Sala, R. (2014). Scanning Electron and Optical Light Microscopy: two complementary approaches for the understanding and interpretation of usewear and residues on stone tools. Journal of Archaeological Science 48, 46-59. https://doi.org/10/gd6cng

Brown, C. A., Hansen, H. N., Jiang, X. J., Blateyron, F., Berglund, J., Senin, N., Bartkowiak, T., Dixon, B., Le Goïc, G., Quinsat, Y., Stemp, W. J., Thompson, M. K., Ungar, P. S. \& Zahouani, E. H. (2018). Multiscale analyses and characterizations of surface topographies. CIRP Annals 67, 839-862. https://doi. org/10.1016/j.cirp.2018.06.001

Burroni, D., Donahue, R. E., Pollard, A. M. \& Mussi, M. (2002). The surface alteration features of flint artefacts as a record of environmental processes. Journal of Archaeological Science 29, 1277-1287. https:// doi.org/10.1006/jasc.2001.0771

Calandra, I., Schunk, L., Rodriguez, A., Gneisinger, W., Pedergnana, A., Paixao, E., Pereira, T., Iovita, R. \& Marreiros, J. (2019a). Back to the edge: relative coordinate system for use-wear analysis. Archaeological and Anthropological Sciences. https://doi.org/10.1007/s12520-019-00801-y

Calandra, I., Schunk, L., Bob, K., Gneisinger, W., Pedergnana, A., Paixao, E., Hildebrandt, A. \& Marreiros, J. (2019b). The effect of numerical aperture on quantitative use-wear studies and its implication on reproducibility. Scientific Reports 9, 1-10. https://doi.org/10.1038/s41598-019-42713-w 
Antony Borel et al. • Kárpát-medencei nyersanyagokból készült köeszközök felületi elváltozásainak elemzése

Calandra, I., Gneisinger, W. \& Marreiros, J. (2020). A versatile mechanized setup for controlled experiments in archeology. STAR: Science \& Technology of Archaeological Research 6 (1), 30-40. https://doi.org/10.1 $\underline{080 / 20548923.2020 .1757899}$

Chan, B., Gibaja, J. F., García-Díaz, V., Hoggard, C. S., Mazzucco, N., Rowland, J. T. \& Gijn, A. V. (2020). Towards an understanding of retouch flakes: A use-wear blind test on knapped stone microdebitage. PLOS ONE 15, e0243101. https://doi.org/10.1371/journal.pone.0243101

Coutier, L. (1929). Expériences de taille pour rechercher les anciennes techniques paléolithiques. Bulletin de la Société préhistorique française 26, 172-174.

Dibble, H. L. (1997). Platform variability and flake morphology: A comparison of experimental and archaeological data and implications for interpreting Prehistoric lithic technological strategies. Lithic Technology 22, 150-170. https://doi.org/10.1080/01977261.1997.11754540

Dibble, H. L. \& Pelcin, A. (1995). The effect of hammer mass and velocity on flake mass. Journal of Archaeological Science 22, 429-439. https://doi.org/10.1006/jasc.1995.0042

Driscoll, K. \& García-Rojas, M. (2014). Their lips are sealed: identifying hard stone, soft stone, and antler hammer direct percussion in Palaeolithic prismatic blade production. Journal of Archaeological Science 47, 134-141. https://doi.org/10.1016/j.jas.2014.04.008

Dumont, J. (1982). The quantification of microwear traces: A new use for interferometry. World Archaeology $14,206-217$.

Eren, M. I., Roos, C. I., Story, B. A., Cramon-Taubadel, N. von \& Lycett, S. J. (2014). The role of raw material differences in stone tool shape variation: an experimental assessment. Journal of Archaeological Science 49, 472-487. https://doi.org/10.1016/j.jas.2014.05.034

Evans, A. A. \& Donahue, R. E. (2008). Laser scanning confocal microscopy: a potential technique for the study of lithic microwear. Journal of Archaeological Science 35, 2223-2230. https://doi.org/10.1016/j. jas.2008.02.006

Evans, A. A. \& Macdonald, D. (2011). Using metrology in early prehistoric stone tool research: further work and a brief instrument comparison. Scanning 33, 294-303. https://doi.org/10.1002/sca.20272

Grace, R., Graham, I. D. G. \& Newcomer, M. H. (1985). The quantification of microwear polishes. World Archaeology 17, 112-120.

Hurcombe, L. (1988). Some criticisms and suggestions in response to Newcomer et al. (1986). Journal of Archaeological Science 15, 1-10. https://doi.org/10.1016/0305-4403(88)90014-3

Ibáñez, J. J., González-Urquijo, J. E. \& Gibaja, J. (2014). Discriminating wild vs. domestic cereal harvesting micropolish through laser confocal microscopy. Journal of Archaeological Science, Lithic Microwear Method: Standardisation, Calibration and Innovation 48, 96-103. https://doi.org/10.1016/j.jas.2013.10.012

Ibáñez, J. J., Anderson, P. C., González-Urquijo, J. \& Gibaja, J. (2016). Cereal cultivation and domestication as shown by microtexture analysis of sickle gloss through confocal microscopy. Journal of Archaeological Science 73, 62-81. https://doi.org/10.1016/j.jas.2016.07.011 
Antony Borel et al. • Kárpát-medencei nyersanyagokból készült köeszközök felületi elváltozásainak elemzése

Ibáñez, J. J., Lazuen, T. \& González-Urquijo, J. (2019). Identifying experimental tool use through confocal microscopy. Journal of Archaeological Method and Theory 26, 1176-1215. https://doi.org/10.1007/s10816$\underline{018-9408-9}$

Inizan, M.-L., Reduron-Ballinger, M., Roche, H. \& Tixier, J. (eds) (1999). Technology and Terminology of Knapped Stone. Préhistoire de la pierre taillée. Nanterre: CREP.

Keeley, L. H. (1980). Experimental Determination of Stone Tool Uses: A microwear analysis. Chicago: University of Chicago Press.

Key, A., Fisch, M. R. \& Eren, M. I. (2018). Early stage blunting causes rapid reductions in stone tool performance. Journal of Archaeological Science 91, 1-11. https://doi.org/10.1016/j.jas.2018.01.003

Key, A. J. M., Stemp, W. J., Morozov, M., Proffitt, T. \& Torre, I. de la (2015). Is loading a significantly influential factor in the development of lithic microwear? an experimental test using LSCM on basalt from Olduvai Gorge. Journal of Archaeological Method and Theory 22, 1193-1214. https://doi.org/10.1007/ $\underline{\mathrm{s} 10816-014-9224-9}$

Lengyel, G. \& Chu, W. (2016). Long thin blade production and Late Gravettian hunter-gatherer mobility in Eastern Central Europe. Quaternary International, The Lithic Issues of the Gravettian 406, 166-173. https://doi.org/10.1016/j.quaint.2016.01.020

Macdonald, D. A. (2014). The application of focus variation microscopy for lithic use-wear quantification. Journal of Archaeological Science, Lithic Microwear Method: Standardisation, Calibration and Innovation 48, 26-33. https://doi.org/10.1016/j.jas.2013.10.003

Mester, Z., Faragó, N. \& Lengyel, G. (2012). The lithic raw material sources and interregional human contacts in the northern Carpathian regions: a research program. Anthropologie 50, 275-293.

Moss, E. H. (1987). A review of "Investigating microwear polishes with blind tests." Journal of Archaeological Science 14, 473-481. https://doi.org/10.1016/0305-4403(87)90033-1

Newcomer, M., Grace, R. \& Unger-Hamilton, R. (1986). Investigating microwear polishes with blind tests. Journal of Archaeological Science 13, 203-217. https://doi.org/10.1016/0305-4403(86)90059-2

Odell, G. H. \& Odell-Vereecken, F. (1980). Verifying the reliability of lithic use-wear assessments by "blind tests": the low-power approach. Journal of Field Archaeology 7, 87-120. https://doi. org/10.2307/529584

Ollé, A. \& Vergès, J. M. (2014). The use of sequential experiments and SEM in documenting stone tool microwear. Journal of Archaeological Science 48, 60-72. https://doi.org/10/gd6c46

Pelegrin, J. (2000). Les techniques de débitage laminaire au Tardiglaciaire: critères de diagnose et quelques réflexions. In: L'Europe Centrale et Septentrionale Au Tardiglaciaire. Actes de La Table-Ronde de Nemours, 13-16 Mai 1997, Mémoires Du Musée de Préhistoire d'Île de France (pp. 73-86). Nemours: APRAIF.

Pfleging, J. (2019). On the Foundations of Robotic Use-wear Analysis: Improving Archaeological Methods for Artefact Characterization with Robotics Technology. PhD Thesis. ETH Zurich. 
Antony Borel et al. • Kárpát-medencei nyersanyagokból készült köeszközök felületi elváltozásainak elemzése

Pfleging, J., Stücheli, M., Iovita, R. \& Buchli, J. (2015). Dynamic monitoring reveals motor task characteristics in Prehistoric technical gestures. PLOS ONE 10, e0134570. https://doi.org/10.1371/journal. pone. 0134570

Pfleging, J., Iovita, R. \& Buchli, J. (2019). Influence of force and duration on stone tool wear: results from experiments with a force-controlled robot. Archaeological and Anthropological Sciences 11, 5921-5935. https://doi.org/10.1007/s12520-018-0729-0

Pichon, F., Ibáñez-Estevez, J. J., Anderson, P. C., Douché, C. \& Coqueugniot, É. (2021). Harvesting cereals at Dja'de el-Mughara in the northern Levant: New results through microtexture analysis of Early PPNB sickle gloss (11th millennium cal BP). Journal of Archaeological Science: Reports 36, 102807. doi: https:// doi.org/10.1016/j.jasrep.2021.102807

Qiu, X. (2016). Robotic system allowing the creation of reference traces corpus for the interpretation of the use of prehistoric stone tools (MA thesis). Université Pierre \& Marie Curie, Muséum National d'Histoire Naturelle, Paris.

Rodriguez, A., Yanamandra, K., Witek, L., Wang, Z., Behera, R. K. \& Iovita, R. (2021). The effect of worked material hardness on stone tool wear. OSF Preprints. https://doi.org/10.31219/osf.io/uhkbr

Rots, V., Pirnay, L., Pirson, Ph. \& Baudoux, O. (2006). Blind tests shed light on possibilities and limitations for identifying stone tool prehension and hafting. Journal of Archaeological Science 33, 935-952. https:// doi.org/10.1016/j.jas.2005.10.018

Semenov, S. A. (1964). Prehistoric Technology: An experimental study of the oldest tools and artefacts from traces of manufacture and wear. London: Bath, Adams \& Dart.

Semenov, S. A. (1970). The forms and funktions of the oldest tools. Quartär 21, 1-20.

Semenov, S. A. \& Shchelinsky, V. E. (1971). Micrometric study of working traces on the Palaeolithic tools. Sovetskaya arkheologiya 1, 19-30.

Stemp, W.J ., Watson, A. S. \& Evans, A. A. (2015). Surface analysis of stone and bone tools. Surface Topography: Metrology and Properties 4, 013001. https://doi.org/10/gft6dz

Stemp, W. J., Lerner, H. J. \& Kristant, E. H. (2018). Testing Area-Scale Fractal Complexity (Asfc) and Laser Scanning Confocal Microscopy (LSCM) to document and discriminate microwear on experimental quartzite scrapers. Archaeometry 60, 660-677. https://doi.org/10.1111/arcm.12335

Tixier, J. (1963). Typologie de l'épipaléolithique du Maghreb, Mémoires du Centre de Recherches anthropologiques, préhistoriques et ethnographiques Alger. Arts et métiers graphiques, Paris.

Tixier, J. (1982). Techniques de débitage: osons ne plus affirmer. In: Tailler ! Pourquoi Faire : Préhistoire et Technologie Lithique II. Recent Progress in Microwear Studies (pp. 13-22). Studia Praehistorica Belgica. Tervuren: Musée Royal de l'Afrique centrale.

Tomenchuk, J. (1983). Predicting the past : examples from the use-wear study of selected chipped stone tools, from two epipalaeolithic occupations in Israël. MOM Éditions 5, 57-76. 
Antony Borel et al. • Kárpát-medencei nyersanyagokból készült köeszközök felületi elváltozásainak elemzése

Tomenchuk, J. (1988). Effects of loading rate on the reliability of engineering use-wear models. In: Beyries, S. (ed.), Industries Lithiques: Tracéologie et Technologie, Vol. 2 (pp. 99-113). BAR International Series. Oxford: Archaeopress. 